Technological University Dublin

DƯBLIN

ARROW@TU Dublin

2010-01-01

\title{
Evaluation of Phase Change Materials for Thermal Regulation Enhancement of Building Integrated Photovoltaics
}

A. Hasan

Sarah McCormack

Technological University Dublin

M. Huang

See next page for additional authors

Follow this and additional works at: https://arrow.tudublin.ie/dubenart

\section{Recommended Citation}

Hasan, A., et al (2010). Evaluation of phase change materials for thermal regulation enhancement of building integrated photovoltaics. Solar Energy, vol. 84,no 9, pp. 1601-1612. doi:10.1016/ j.solener.2010.06.010

This Article is brought to you for free and open access by the Dublin Energy Lab at ARROW@TU Dublin. It has been accepted for inclusion in Articles by an authorized administrator of ARROW@TU Dublin. For more information, please contact arrow.admin@tudublin.ie, aisling.coyne@tudublin.ie,gerard.connolly@tudublin.ie. 
Authors

A. Hasan, Sarah McCormack, M. Huang, and Brian Norton

This article is available at ARROW@TU Dublin: https://arrow.tudublin.ie/dubenart/37 


\title{
Evaluation of phase change materials for thermal regulation enhancement of building integrated photovoltaics
}

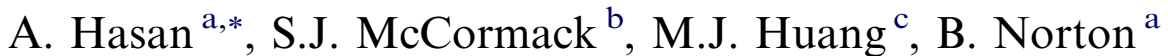 \\ ${ }^{a}$ Dublin Energy Lab., Focas Institute, School of Physics, Dublin Institute of Technology, Kevin St., Dublin 8, Ireland \\ ${ }^{\mathrm{b}}$ Department of Civil, Structure and Environmental Engineering, Trinity College Dublin, Dublin 1, Ireland \\ ${ }^{\mathrm{c}}$ Centre for Sustainable Technologies, University of Ulster, Newtownabbey, N. Ireland, BT370QB, UK
}

Received 22 September 2009; received in revised form 20 May 2010; accepted 21 June 2010

Communicated by: Associate Editor Harvey Bryan

\begin{abstract}
Regulating the temperature of building integrated photovoltaics (BIPV) using phase change materials (PCMs) reduces the loss of temperature dependent photovoltaic (PV) efficiency. Five PCMs were selected for evaluation all with melting temperatures $\sim 25 \pm 4{ }^{\circ} \mathrm{C}$ and heat of fusion between 140 and $213 \mathrm{~kJ} / \mathrm{kg}$. Experiments were conducted at three insolation intensities to evaluate the performance of each PCM in four different PV/PCM systems. The effect on thermal regulation of PV was determined by changing the (i) mass of PCM and (ii) thermal conductivities of the PCM and PV/PCM system. A maximum temperature reduction of $18^{\circ} \mathrm{C}$ was achieved for $30 \mathrm{~min}$ while $10^{\circ} \mathrm{C}$ temperature reduction was maintained for $5 \mathrm{~h}$ at $-1000 \mathrm{~W} / \mathrm{m}^{2}$ insolation.
\end{abstract}

(c) 2010 Elsevier Ltd. All rights reserved.

Keywords: Phase change materials (PCM); Building integrated photovoltaics (BIPV); Thermal regulation enhancement

\section{Introduction}

\subsection{Thermal management of photovoltaics}

The operating temperature of $\mathrm{PV}$ can be as high as $80^{\circ} \mathrm{C}$ at higher solar radiation intensities that raises the intrinsic carrier concentration in crystalline silicon photovoltaic $(\mathrm{PV})$ cells causing a higher saturation current and lower voltage of the cells (Mazer, 1997). The temperature induced

\footnotetext{
Abbreviations: PCM, phase change material; PV, photovoltaics; BIPV, building integrated photovoltaics; $\mathrm{CFD}$, computational fluid dynamics; $\mathrm{PV} / \mathrm{T}$, photovoltaic thermal; DSC, differential scanning calorimetry; RT20, commercial paraffin based phase change material; SP22, commercial blend of salt hydrate and paraffin phase change material; CL, eutectic mixture of capric lauric acid; $\mathrm{CP}$, eutectic mixture of capric-palmitic acid; $\mathrm{CaCl}_{2}$, calcium chloride hexa hydrate.

* Corresponding author. Tel.: +353 14027963.

E-mail address: ahmad.hasan@dit.ie (A. Hasan).
}

increase in current is less than the concomitant decrease in voltage yielding a net decrease in the power output of the PV (Radziemska and Klugman, 2002). Measuring the power-voltage characteristics of PV at different temperatures enables a temperature-dependent power loss coefficient to be determined (Raziemska, 2003). Crystalline silicon PV operating above $25^{\circ} \mathrm{C}$ typically, shows a temperature-dependent power decrease with a coefficient of between $0.4 \% / \mathrm{K}$ (Weakliem and Redfield, 1979; Krauter, 1994 ) and $0.65 \% / \mathrm{K}$ (Raziemska, 2003). Overall integration of PV into buildings has been shown to further rise PV operating temperature to such an extent that there has been reported a $9.3 \%$ further decreased power output compared to nonintegrated PV (Krauter et al., 1999). This emphasizes a need for effective temperature regulation of building integrated photovoltaics (BIPV). Different heat removal techniques employed to maintain PV at lower temperatures are summarised in Table 1. 


\section{Nomenclature}

$l \quad$ length of the duct $(\mathrm{m})$

$D \quad$ diameter of the duct (m)

$Q \quad$ heat absorbed by phase change material $(\mathrm{kJ})$

$C_{\mathrm{ps}} \quad$ specific heat capacity of phase change material in solid phase $(\mathrm{kJ} / \mathrm{kg} \mathrm{K})$

$C_{\mathrm{pl}} \quad$ specific heat capacity of phase change material in liquid phase $(\mathrm{kJ} / \mathrm{kg} \mathrm{K})$

$T_{\mathrm{m}} \quad$ melting point of phase change material $\left({ }^{\circ} \mathrm{C}\right)$

$T_{\mathrm{i}} \quad$ initial temperature of phase change material $\left({ }^{\circ} \mathrm{C}\right)$

$T_{\mathrm{f}} \quad$ final temperature of phase change material $\left({ }^{\circ} \mathrm{C}\right)$

$L \quad$ latent heat of fusion of phase change material $(\mathrm{kJ} / \mathrm{kg})$ $m \quad$ mass of phase change material $(\mathrm{kg})$

$T_{\mathrm{PV}} \quad$ temperature at front surface of $\mathrm{PV}\left({ }^{\circ} \mathrm{C}\right)$

$T_{\mathrm{PVPCM}}$ temperature at front surface of $\mathrm{PV} / \mathrm{PCM}$ system $\left({ }^{\circ} \mathrm{C}\right)$

$T$ temperature $\left({ }^{\circ} \mathrm{C}\right)$

$t_{0} \quad$ time at the start of the experiment (s)

$t_{n} \quad$ time at the $n$th reading of the experiment (s)

$P_{\mathrm{L}} \quad$ power output from loaded $\mathrm{PV}(\mathrm{W})$

$P_{\mathrm{Lmax}}$ maximum power output from loaded PV (W)

$U_{\mathrm{L}} \quad$ voltage of loaded PV (V)

$\Gamma \quad$ thermal regulation enhancement $\left({ }^{\circ} \mathrm{C} \min \right)$
In non BIPV systems, passive heat removal from PV is usually effected by buoyant circulation of air in a duct behind the PV (Yang et al., 1994; Brinkworth, 2000a, b). Heat removal from the PV depends on depth to hydraulic diameter ratio $(l / D)$ of the duct (Brinkworth and Sandberg, 2006). The maximum heat removal has been shown to occur at a duct $l / D$ of 20 , resulting minimum temperature $\left(\sim 34^{\circ} \mathrm{C}\right)$ in a PV subjected to $50 \mathrm{~W} / \mathrm{m}^{2}$ heat flux with $5 \mathrm{~m}$ duct length (Brinkworth, 2006).

In BIPV systems passive heat removal also relies on buoyant circulation of air in an opening or air channel instead of a duct behind the PV. CFD modelling of natural ventilation in an atrium-integrated PV suggested that a properly located opening close to the roof can induce air flow in the room and regulate PV operating temperature (Gan and Riffat, 2004). A theoretical analysis of a natural ventilated façade integrated PV with an opening behind the PV has been carried out in three locations, Stockholm, London and Madrid. A maximum $5{ }^{\circ} \mathrm{C}$ temperature reduction in monthly temperature due to natural ventilation yielded an annual $2.5 \%$ increase in electrical output of the PV (Yun et al., 2007). Improvements in natural ventilation PV façade have been achieved by suspending a metal sheet in the air channel, inserting fins and optimizing the distance between the air duct walls (Tonui and Tripanagnostopoulos, 2007; Fossa et al., 2008).

Hydraulic cooling of PV relies on water at front or back surface of the PV. Flowing water on the front surface of PV has been shown to decrease cell temperature up to $22^{\circ} \mathrm{C}$ along with decreasing reflection losses yielding an overall $8-9 \%$ increase in PV electrical power output (Krauter, 2004). Water flow on the back of a façade integrated PV/T has been modelled to arrive at an optimum thermal and electrical performance. This was $0.05 \mathrm{~kg} / \mathrm{s}$ for a particular system in the weather conditions of Hefei (China) at insolations of $405 \mathrm{~W} / \mathrm{m}^{2}$ and $432 \mathrm{~W} / \mathrm{m}^{2}$ (Ji et al., 2006).

\subsection{Phase change materials for thermal management applications}

Solid-liquid phase change materials have been used as temperature regulators in different applications $(\mathrm{Lu}, 2000$; Tan and Fok, 2007; Kandasamy et al., 2006; Wang et al., 2007; Pasupathy et al., 2006, 2008 Sabbahet al., 2008; Pasupathy and Velraj, 2008; Weinstein et al., 2008; Fleischer et al., 2008; Khateeb et al., 2004a, b). A one dimensional heat transfer model was developed to study the cooling effect produced by integrated PCM in electronic packaging and a design optimization was reported ( $\mathrm{Lu}, 2000)$.

The cooling effect produced by a PCM heat storage unit (HSU) integrated into a mobile phone was studied numerically. It was concluded that use of such systems in mobile phones was effective at higher heat fluxes (Tan and Fok, 2007). The use of PCM contained in portable electronics packaging was studied numerically and validated experimentally. The effect of heat dissipation rate, the thermal resistance of packaging and orientation of the packaging to gravity on the cooling performance of PCM was studied. It was concluded that heat dissipation rate and thermal resistance of packaging has important while orientation of packaging to gravity has trivial effect on cooling performance of PCM (Kandasamy et al., 2006; Wang et al., 2007). PCMs have been used as temperature regulator to maintain human comfort temperature in built environment to store heat during day time or coolness during night time to reduce the temperature swing (Pasupathy et al., 2006; Sabbah et al., 2008; Pasupathy and Velraj, 2008).

An important problem related to the PCM restricting efficient heat removal is their low thermal conductivity. Different techniques have been employed to improve the thermal conductivity of PCM (Pasupathy et al., 2008; Weinstein et al., 2008; Fleischer et al., 2008; Khateeb et al., 2004a, b). The PCM integrated in aluminium foam were investigated for the cooling of Li-ion battery in a scooter with arrangement of aluminium foam and fins to 
Table 1

Advantages and disadvantages of different thermal management techniques.

\begin{tabular}{|c|c|c|c|c|c|c|}
\hline & $\begin{array}{l}\text { Natural air } \\
\text { circulation }\end{array}$ & Forced air circulation & Hydraulic cooling & Heat pipes & $\begin{array}{l}\text { Thermoelectric } \\
\text { (Peltier) cooling }\end{array}$ & $\begin{array}{l}\mathrm{PCM} \text { thermal } \\
\text { management }\end{array}$ \\
\hline Advantages & $\begin{array}{l}\text { - low initial cost } \\
\text { - no maintenance } \\
\text { - easy to integrate } \\
\text { - longer life } \\
\text { - no noise electricity } \\
\text { - no } \\
\text { consumption } \\
\text { - passive heat exchange }\end{array}$ & $\begin{array}{l}\text { - higher heat transfer rates com- } \\
\text { pared to natural circulation of } \\
\text { air } \\
\text { - independent of wind direction } \\
\text { and speed } \\
\text { - higher mass flow rates than } \\
\text { natural air circulation achiev- } \\
\text { ing high heat transfer rates } \\
\text { - higher temperature reduction } \\
\text { compared to natural air } \\
\text { circulation }\end{array}$ & $\begin{array}{l}\text { - higher heat transfer rate } \\
\text { compared to natural and } \\
\text { forced circulation of air } \\
\text { - higher mass flow rates } \\
\text { compared to natural and } \\
\text { forced circulation of air } \\
\text { - higher thermal conductiv- } \\
\text { ity and heat capacity of } \\
\text { water compared to air } \\
\text { - higher temperature } \\
\text { reduction }\end{array}$ & $\begin{array}{l}\text { - passive heat } \\
\text { exchange } \\
\text { - low cost } \\
\text { - easy to } \\
\text { integrated }\end{array}$ & $\begin{array}{l}\text { - no moving parts } \\
\text { - noise Free } \\
\text { - small size } \\
\text { - easy to integrate } \\
\text { - low maintenance costs } \\
\text { - solid state heat transfer }\end{array}$ & $\begin{array}{l}\text { - higher heat transfer rates com- } \\
\text { pared to both forced air circula- } \\
\text { tion and forced water circulation } \\
\text { - higher heat absorption due to } \\
\text { latent heating } \\
\text { - isothermal natural of heat removal } \\
\text { - no electricity consumption } \\
\text { - passive heat exchange } \\
\text { - no noise } \\
\text { - no maintenance cost } \\
\text { - on demand heat delivery }\end{array}$ \\
\hline Disadvantages & $\begin{array}{l}\text { - low heat transfer rates } \\
\text { - accumulation of dust in } \\
\text { inlet grating further } \\
\text { reducing heat transfer } \\
\text { - dependent on wind } \\
\text { direction and speed } \\
\text { - low thermal conductiv- } \\
\text { ity and heat capacity } \\
\text { of air } \\
\text { - low mass flow rates of } \\
\text { air } \\
\text { - limited temperature } \\
\text { reduction }\end{array}$ & $\begin{array}{l}\text { - high initial cost for fans, ducts } \\
\text { to handle large mass flow rates } \\
\text { - high electrical consumption } \\
\text { - maintenance cost } \\
\text { - noisy system } \\
\text { - difficult to integrate compared } \\
\text { to natural air circulation } \\
\text { system }\end{array}$ & $\begin{array}{l}\text { - higher initial cost due to } \\
\text { pumps } \\
\text { - higher maintenance cost } \\
\text { compared to forced air } \\
\text { circulation } \\
\text { - higher electricity con- } \\
\text { sumption compared to } \\
\text { forced air circulation, } \\
\text { - less life compared to } \\
\text { forced air circulation due } \\
\text { to corrosion }\end{array}$ & $\begin{array}{l}\text { - low heat } \\
\text { transfer rates } \\
\text { - dust accu- } \\
\text { mulation on } \\
\text { the inlet } \\
\text { grating } \\
\text { - dependent } \\
\text { on the wind } \\
\text { speed and } \\
\text { direction }\end{array}$ & $\begin{array}{l}\text { - heat transfer depends on } \\
\text { ambient conditions } \\
\text { - active systems } \\
\text { - require electricity } \\
\text { - reliability issues -costly } \\
\text { for PV cooling } \\
\text { - no heat storage capacity } \\
\text { - requires efficient heat } \\
\text { removal from warmer } \\
\text { side for effective cooling }\end{array}$ & $\begin{array}{l}\text { - higher PCM cost compared to } \\
\text { both } \\
\text { - some PCMs are toxic } \\
\text { - some PCMs have fire safety issues } \\
\text { - some PCMs are strongly corrosive } \\
\text { - PCMs may have disposal problem } \\
\text { after their life cycle is complete }\end{array}$ \\
\hline
\end{tabular}


overcome low PCM thermal conductivity. It was observed that PCM integrated in aluminium foam achieved higher cooling compared to cooling by aluminium foam only and the cooling by PCM only (Pasupathy et al., 2008; Weinstein et al., 2008). PCM was used in a graphite-matrix to improve heat removal by increasing thermal conductivity and its performance was compared with active air blow cooling to cool Li-ion battery. It was concluded that at high temperatures and battery discharge rates, the passive PCM-graphite cooling was more effective than active air cooling (Fleischer et al., 2008). Graphite nanofibers were embedded into PCM at various weight ratios to enhance their thermal conductivity. A decrease in melting time and temperature in the PCM with increasing graphite nanofibers loading was observed (Khateeb et al., 2004a, 2004b).

PCMs were first evaluated experimentally for BIPV temperature regulation by Huang et al. (2004). The PCM was contained in an aluminium box with its front surface coated with a solar selective absorbing material to mimic a PV cell attached to its front. Temperature distributions on the front surface and inside a paraffin wax RT25 PCM were studied with and without metallic fins at $-750 \mathrm{~W} / \mathrm{m}^{2}$ insolation. 2D and $3 \mathrm{D}$ finite volume heat transfer simulation models were developed to study PCM performance for BIPV thermal regulation. Model predictions were found in good agreement with experimental results (Huang et al., 2006a,b). In recent work PV module was attached to a rectangular aluminium box containing eutectic mixture of capric-lauric acid $(\mathrm{C}-\mathrm{L})$ which were irradiated at $415 \mathrm{~W} / \mathrm{m}^{2}$. A $10{ }^{\circ} \mathrm{C}$ temperature reduction was achieved for $\sim 6 \mathrm{~h}$ compared to a PV attached to the box without PCM (Hasan et al., 2007).

\subsection{Thermal regulation enhancement using PCM}

The PCM can remove thermal energy available at PV and maintain lower temperature during melting. Heat removed by PCM is sum of the sensible heat absorbed when its temperature rises from ambient temperature to its melting point, the latent heat absorbed during melting and the sensible heat from end of melting until it reaches a peak equilibrium temperature. This can be represented by Eq. (1).

$Q=m C_{p s}\left(T_{m}-T_{i}\right)+m L+m C_{p l}\left(T_{f}-T_{m}\right)$

The difference between temperature evolution of a reference PV system without PCM and PV system with PCM as shown in Appendix A is a measure of the total thermal regulation enhancement, $\Gamma$ provided using PCM. Mathematically $\Gamma$ for a particular PCM at constant insolation and ambient temperature is obtained by subtracting the integral of PV temperature evolution with PCM ( $\left.T_{\mathrm{PVPCM}}\right)$ with time from the integral of reference PV temperature evolution $\left(T_{\mathrm{PV}}\right)$ with time as shown in Appendix B, i.e.

$\Gamma=\int_{t=t_{0}}^{t=t_{n}} T_{\mathrm{PV}} d t-\int_{t=t_{0}}^{t=t_{n}} T_{\mathrm{PVPCM}} d t$

when the test conditions are identical for both the PV and the PV/PCM systems, the Eq. (2) becomes:

$\Gamma=\int_{t=t_{0}}^{t=t_{n}}\left(T_{\mathrm{PV}}-T_{\mathrm{PVPCM}}\right) d t$

while for $n$ discrete measurements of $T_{\mathrm{PV}}$ and $T_{\mathrm{PVPCM}}$ under identical conditions, the thermal regulation enhancement becomes

$\Gamma=\sum_{t=0}^{t=n}\left(T_{\mathrm{PV}, t}-T_{\mathrm{PVPCM}, t}\right)$

\section{Experimental procedure}

In this work, the five PCM presented in Table 2 were selected with melting points $25 \pm 4{ }^{\circ} \mathrm{C}$ and heats of fusion $140-213 \mathrm{~kJ} / \mathrm{kg}$. The thermophysical properties of melting onset, melting peak, heat of fusion and super cooling/subcooling of PCM were measured with differential scanning calorimetry (DSC) and a temperature history method (Hasan et al., 2008).

\subsection{Fabrication of experimental system}

Polycrystalline silicon PV cells with dimensions of $10 \mathrm{~cm} \times 10 \mathrm{~cm} \times 0.05 \mathrm{~cm}$ were encapsulated between two

Table 2

Thermophysical properties of selected PCMs studied (Hasan et al., 2007).

\begin{tabular}{|c|c|c|c|c|c|}
\hline & \multicolumn{5}{|l|}{ PCM } \\
\hline & $\begin{array}{l}\text { Paraffin wax } \\
\text { (RT20) }\end{array}$ & $\begin{array}{l}\text { Eutectic mixture of } \\
\text { capric-lauric acid }(\mathrm{C}-\mathrm{L})\end{array}$ & $\begin{array}{l}\text { Eutectic mixture of } \\
\text { capric-palmitic acid (C-P) }\end{array}$ & $\begin{array}{l}\text { Pure salt hydrate } \\
\left(\mathrm{CaCl}_{2} \cdot 6 \mathrm{H}_{2} \mathrm{O}\right)\end{array}$ & $\begin{array}{l}\text { Commercial } \\
\text { blend (SP22) }\end{array}$ \\
\hline Melting onset, ${ }^{\circ} \mathrm{C}$ & 21.23 & 20.78 & 22.33 & 29.17 & 22.97 \\
\hline Melting peak, ${ }^{\circ} \mathrm{C}$ & 25.73 & 24.66 & 26.4 & 29.66 & 24.6 \\
\hline Heat of fusion, $\mathrm{kJ} / \mathrm{kg}$ & 140.3 & 171.98 & 196.07 & 213.12 & 182 \\
\hline Thermal conductivity, $\mathrm{W} / \mathrm{m} \mathrm{K}$ & 0.2 & 0.139 & 0.143 & 1.09 & 0.6 \\
\hline Density solid, $\mathrm{kg} / \mathrm{l}$ & 0.88 & 0.88 & 0.883 & 1.71 & 1.49 \\
\hline Sub-cooling, ${ }^{\circ} \mathrm{C}$ & Negligible & Negligible & Negligible & 5 & 8 \\
\hline Specific heat capacity (solid), $\mathrm{kJ} / \mathrm{kg} \mathrm{K}$ & $1.8-2.4$ & N/A & N/A & 1.4 & 2.5 \\
\hline
\end{tabular}


Table 3

Fabricated PV/PCM systems.

\begin{tabular}{lllll}
\hline & PV/PCM systems & & & \\
\cline { 2 - 5 } & $\mathrm{A}$ & $\mathrm{B}$ & $\mathrm{C}$ & $\mathrm{D}$ \\
\hline Container material & Aluminium & Perspex & Aluminium & Perspex \\
Thermal conductivity of material $(\mathrm{W} / \mathrm{m} \mathrm{K})$ & 237 & 0.189 & 237 & 0.189 \\
Container width $(\mathrm{cm})$ internal & 5 & 5 & 3 & 3 \\
External wall thickness $(\mathrm{mm})$ & 5 & 10 & 5 & 10 \\
\hline
\end{tabular}

sheets of $3 \mathrm{~mm}$ thick transparent perspex to simulate a cell size section of a PV module. Four rectangular containers, as listed in Table 3, were fabricated and a PV cell was attached to the front of each container as illustrated in Fig. 1. Different container materials and container widths were chosen to observe the effect of (i) heat conductive (A and C) compared with heat insolating (B and D) container walls (ii) thermal mass of PCM on PV thermal regulation at different insolations.

Systems $\mathrm{A}$ and $\mathrm{C}$ were fabricated from high thermal conductivity $(237 \mathrm{~W} / \mathrm{m} \mathrm{K})$ aluminium enabling rapid heat removal from PV into PCM but had less heat retention due to loss of heat to ambient through their conductive surfaces. Systems B and D fabricated from perspex (MARCRYL CLEAR from Vink Plastics) had very low thermal conductivity $(0.189 \mathrm{~W} / \mathrm{m} \mathrm{K})$ thus enabling high heat retention due to thermally insulating side and back perspex plates preventing heat loss to ambient but had slow heat removal from PV into PCM.

\subsection{Data acquisition}

A reference experiment was conducted irradiating the PV section with a GR262 solar simulator producing low $\left(500 \mathrm{~W} / \mathrm{m}^{2}\right)$, intermediate $\left(750 \mathrm{~W} / \mathrm{m}^{2}\right)$ and high $(1000 \mathrm{~W} /$ $\mathrm{m}^{2}$ ) insolations at an ambient temperature of $20 \pm 1^{\circ} \mathrm{C}$. A Kipp and Zonen CM6B pyranometer measured insolation with a maximum measured spatial intensity variation of $\pm 2 \%$ over the PV front surface. Temperature at the PV front surface was measured with five calibrated T-type copper-constantan thermocouples with maximum deviation of $\pm 0.2{ }^{\circ} \mathrm{C}$ placed at the locations illustrated in Fig. 2. Experiments were conducted with each of the selected PCMs contained in systems A, B, C and D under the same test conditions as the reference (i.e., $500 \mathrm{~W} / \mathrm{m}^{2}$, $-750 \mathrm{~W} / \mathrm{m}^{2}$ and $-1000 \mathrm{~W} / \mathrm{m}^{2}$ at $20 \pm 1{ }^{\circ} \mathrm{C}$ ) with the experimental setup shown in the Fig. 3.

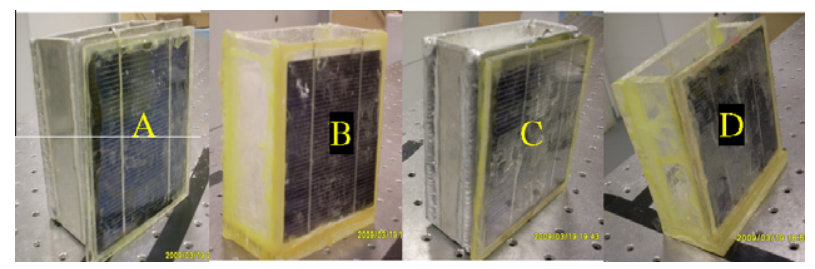

Fig. 1. Photographs of PV/PCM systems A, B, C and D.

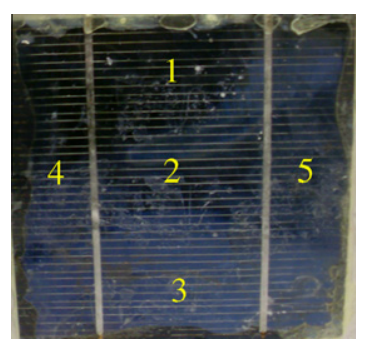

Fig. 2. Position of thermocouples on front surface of the PV section.

\section{Results and discussion}

\subsection{Reference temperatures}

Fig. 4 shows the reference system temperature evolution at the PV front surface for all insolations without PCM. For each experiment the temperature increased rapidly and reached a steady state when heat input to PV due to irradiation equaled the heat lost by PV to ambient primarily due to convection. Reference steady state temperatures, their corresponding insolations and the time elapsed to reach them were, $45^{\circ} \mathrm{C}$ at $500 \mathrm{~W} / \mathrm{m}^{2}$ reached in $80 \mathrm{~min}$, $51{ }^{\circ} \mathrm{C}$ at $750 \mathrm{~W} / \mathrm{m}^{2}$ reached in $40 \mathrm{~min}$ and $57^{\circ} \mathrm{C}$ at $1000 \mathrm{~W} / \mathrm{m}^{2}$ reached in $34 \mathrm{~min}$.

\subsection{Thermal regulation at low insolation}

Fig. 5 presents the temperature on the PV front surface for all PCMs in system A compared with the reference system at $500 \mathrm{~W} / \mathrm{m}^{2}$ insolation and $20 \pm 1^{\circ} \mathrm{C}$ ambient temperature. The reference system temperature reached steady state at $45^{\circ} \mathrm{C}$ in $80 \mathrm{~min}$, the temperature rise with $\mathrm{PCM}$ was also rapid up to $\sim 30^{\circ} \mathrm{C}$ due to sensible heating of solid PCM by conduction heat transfer showing little deviation from the reference system. Corresponding to $30{ }^{\circ} \mathrm{C}$ at PV front surface, the temperature of PCM layer in direct contact with the PV back surface reached its melting point and the PCM started melting and absorbing PV thermal energy as latent heat. The gradient of temperature rise decreased and the temperature at the PV deviated from the reference. After intimate PCM layer had melted, the combination of convection heat transfer in melted PCM and conduction heat transfer in solid PCM continued. The convective heat transfer in melted PCM continued increasing as the melt fraction increased resulting in increased sensible heating 


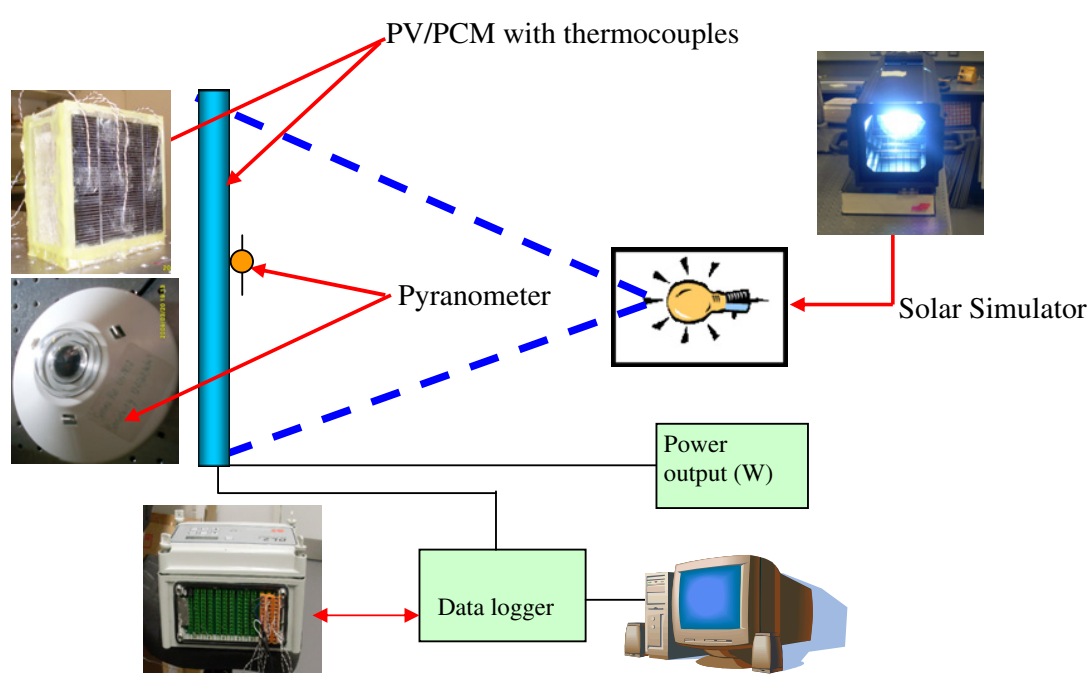

Fig. 3. Schematic of the experimental setup.

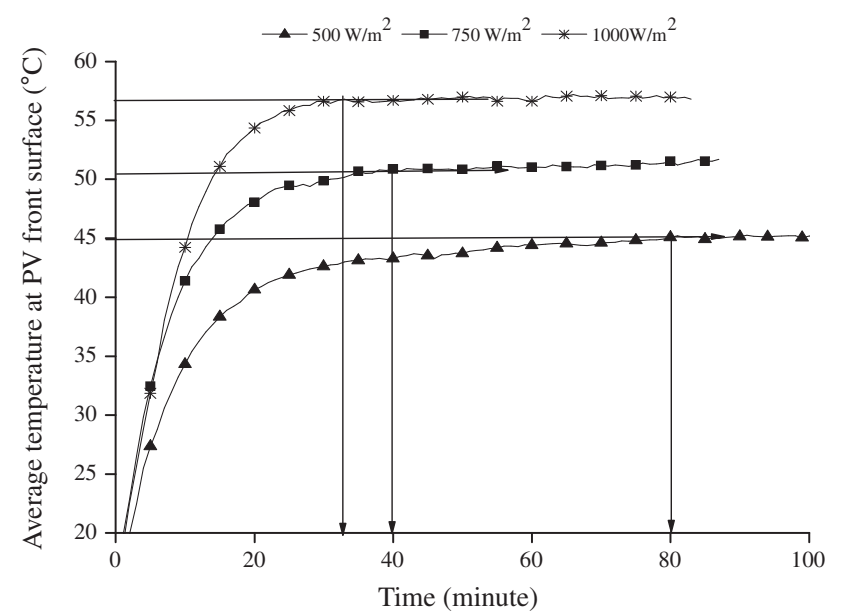

Fig. 4. Reference temperatures at PV front surface at $500 \mathrm{~W} / \mathrm{m}^{2}, 750 \mathrm{~W} /$ $\mathrm{m}^{2}$ and $1000 \mathrm{~W} / \mathrm{m}^{2}$ and ambient temperature of $20 \pm 1{ }^{\circ} \mathrm{C}$.

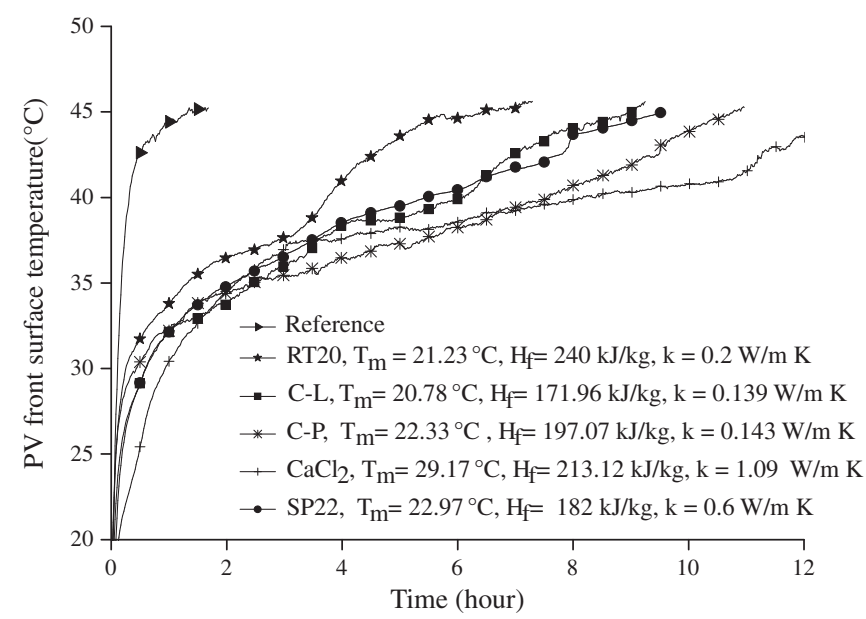

Fig. 5. Temperature evolution on PV front surface in system A at an insolation of $500 \mathrm{~W} / \mathrm{m}^{2}$ and ambient temperature of $20 \pm 1^{\circ} \mathrm{C}$. of the PCM. Heat absorption continued until all of the PCM had melted resulting in convection dominant heat transfer and gradient of the temperature rise started increasing sharply until the PV temperature equaled the reference system temperature at the end of the experiment.

The degree and duration of deviation of PV temperature evolution using PCM from that of the reference system is used to quantify the thermal regulation enhancement provided by each PCM. After $4 \mathrm{~h}$ the deviation for RT20, SP22, $\mathrm{CL}, \mathrm{CaCl}_{2}$ and $\mathrm{CP}$ was $4.6^{\circ} \mathrm{C}, 6.5^{\circ} \mathrm{C}, 7^{\circ} \mathrm{C}, 7.5^{\circ} \mathrm{C}$ and $8{ }^{\circ} \mathrm{C}$ respectively. The duration of the deviation is the time in which temperature on PV containing PCM equaled the reference temperature which is $6.5 \mathrm{~h}, 9 \mathrm{~h}$, $9.5 \mathrm{~h}, 11 \mathrm{~h}$ and $13 \mathrm{~h}$ for RT20, CL, SP22, CP and $\mathrm{CaCl}_{2}$ respectively. RT 20 showed the smallest deviation and shortest duration of deviation while $\mathrm{C}-\mathrm{P}$ showed the largest deviation and $\mathrm{CaCl}_{2}$ showed the longest duration of deviation. Similar trend was observed for systems B, C and D however each PCM showed lower thermal regulation than in system A.

The duration that each PCM maintained a PV temperature of $10^{\circ} \mathrm{C}$ below the reference temperature is illustrated in Fig. 6. All the PCM in system A maintained $10^{\circ} \mathrm{C}$ temperature reduction for a longer duration compared to the same size system B. Similarly PCM in system C maintained a temperature reduction for a longer duration than the same size system D. It can be concluded that at low insolation the PCM performed better in high thermal conductivity containers (A and C) than in low thermal conductivity containers (B and D).

Comparing PCMs, the fatty acids $\mathrm{C}-\mathrm{L}$ and $\mathrm{C}-\mathrm{P}$ maintained $10^{\circ} \mathrm{C}$ temperature deviation from the reference temperature for the longest duration $(2.5 \mathrm{~h})$, followed by salt hydrates SP22 and $\mathrm{CaCl}_{2}(\sim 2.25 \mathrm{~h})$ and paraffin wax RT20 $(\sim 1.5 \mathrm{~h})$. The disadvantage of fatty acids is their low thermal conductivities $(0.139-0.143 \mathrm{~W} / \mathrm{m} \mathrm{K})$ compared to salt hydrates $\mathrm{CaCl}_{2}(1.09 \mathrm{~W} / \mathrm{m} \mathrm{K})$. Since fatty acids per- 


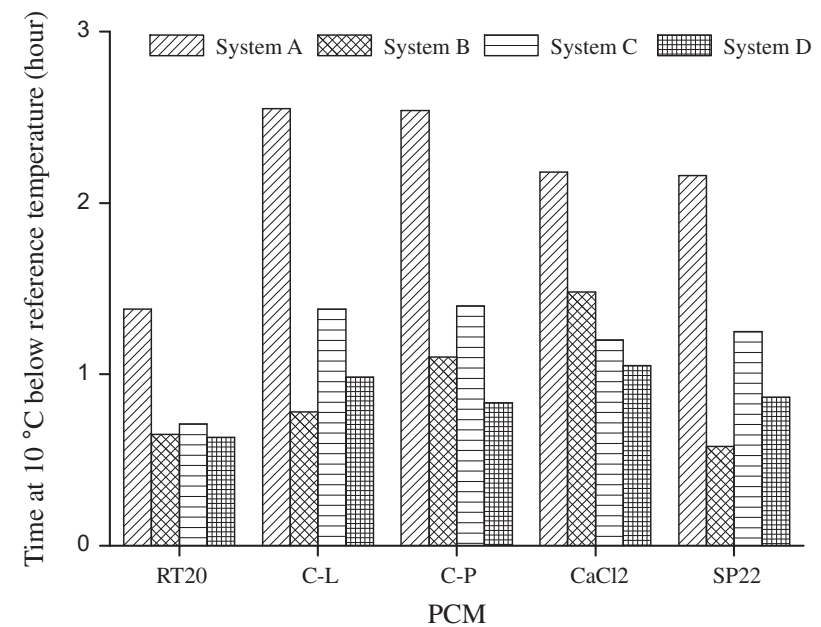

Fig. 6. Duration for which PCM maintained PV front surface temperature $10{ }^{\circ} \mathrm{C}$ below the reference temperature in systems $\mathrm{A}, \mathrm{B}, \mathrm{C}$ and $\mathrm{D}$ at an insolation of $500 \mathrm{~W} / \mathrm{m}^{2}$ and ambient temperature of $20 \pm 1^{\circ} \mathrm{C}$.

formed better than salt hydrates at $-500 \mathrm{~W} / \mathrm{m}^{2}$ in system $\mathrm{A}$, it can be concluded that at low insolation, combination of low thermal conductivity PCMs with high thermal conductivity containers are better than the combination of high thermal conductivity PCM with high thermal conductivity containers.

\subsection{Thermal regulation at intermediate insolation}

Fig. 7 shows temperatures at the PV front surface for all PCMs in system A compared with the reference at $-750 \mathrm{~W} / \mathrm{m}^{2}$ insolation and $20 \pm 1{ }^{\circ} \mathrm{C}$ ambient temperature. After $4 \mathrm{~h}$ the temperature deviation for RT20, SP22, CL, $\mathrm{CP}$ and $\mathrm{CaCl}_{2}$ was $4{ }^{\circ} \mathrm{C} 7.5^{\circ} \mathrm{C}, 8{ }^{\circ} \mathrm{C}, 9^{\circ} \mathrm{C}$, and $10^{\circ} \mathrm{C}$ respectively. The duration of temperature deviation was $6 \mathrm{~h}, 8 \mathrm{~h}, 9 \mathrm{~h}, 10 \mathrm{~h}$ and $12 \mathrm{~h}$ for RT20, CL, SP22, CP and $\mathrm{CaCl}_{2}$ respectively. RT20 showed the smallest temperature

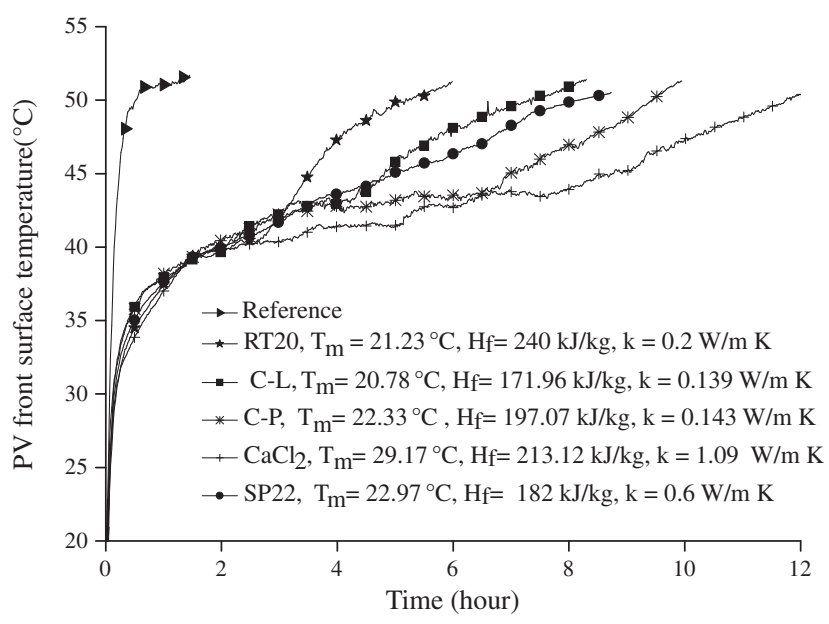

Fig. 7. Temperature evolution on front surface of PV in system $A$ at an insolation of $750 \mathrm{~W} / \mathrm{m} 2$ and ambient temperature of $20 \pm 1{ }^{\circ} \mathrm{C}$. deviation and shortest duration of the deviation while $\mathrm{CaCl}_{2}$ showed the largest temperature deviation and the longest duration of the deviation. Each PCM showed similar behaviour in systems B, C and D however they showed lower temperature deviation and the duration of the deviation than in system A.

The duration for which each PCM maintained PV temperature $10{ }^{\circ} \mathrm{C}$ below reference temperature are illustrated in Fig. 8. Comparing systems A, B, C and D, the temperature reduction of $10^{\circ} \mathrm{C}$ for the longest duration was achieved with system A for all PCMs. Similarly comparing different PCMs, $\mathrm{CaCl}_{2}$ maintained the temperature reduction of $10{ }^{\circ} \mathrm{C}$ for the longest duration $(3.5 \mathrm{~h})$ followed by SP22 (2.7 h) C-P and C-L (2.5 h) and RT20 (2 h). High thermal conductivity PCMs, $\mathrm{CaCl}_{2}$ and $\mathrm{SP} 22$ performed better at $750 \mathrm{~W} / \mathrm{m}^{2}$ than low thermal conductivity PCMs, C-P and C-L, opposite to what was observed at insolation of $500 \mathrm{~W} / \mathrm{m}^{2}$. It can be concluded that at intermediate insolation the optimum performance was achieved with the combination of high thermal conductivity PCMs with high thermal conductivity container A.

\subsection{Thermal regulation at high insolation}

Fig. 9 shows temperatures at the PV front surface for all PCMs in system A compared with the reference at $1000 \mathrm{~W} /$ $\mathrm{m}^{2}$ insolation and $20 \pm 1{ }^{\circ} \mathrm{C}$ ambient temperature. After $4 \mathrm{~h}$ the temperature deviation for RT20, CL, SP22, $\mathrm{CaCl}_{2}$ and $\mathrm{CP}$ was $3.5^{\circ} \mathrm{C}, 4^{\circ} \mathrm{C}, 7.5^{\circ} \mathrm{C}, 11^{\circ} \mathrm{C}$, and $12^{\circ} \mathrm{C}$ respectively. The duration of temperature deviation was $5.5 \mathrm{~h}$, $6 \mathrm{~h}, 9 \mathrm{~h}, 9.5 \mathrm{~h}$ and $11 \mathrm{~h}$ for RT20, CL, SP22, CP and $\mathrm{CaCl}_{2}$ respectively. RT20 showed the smallest temperature deviation and shortest duration of the deviation while C-P showed the largest temperature deviation and $\mathrm{CaCl}_{2}$ showed the longest duration of temperature deviation. Similar PCM behaviour was observed in containers B, C and $\mathrm{D}$, however each PCM showed lower temperature reg-

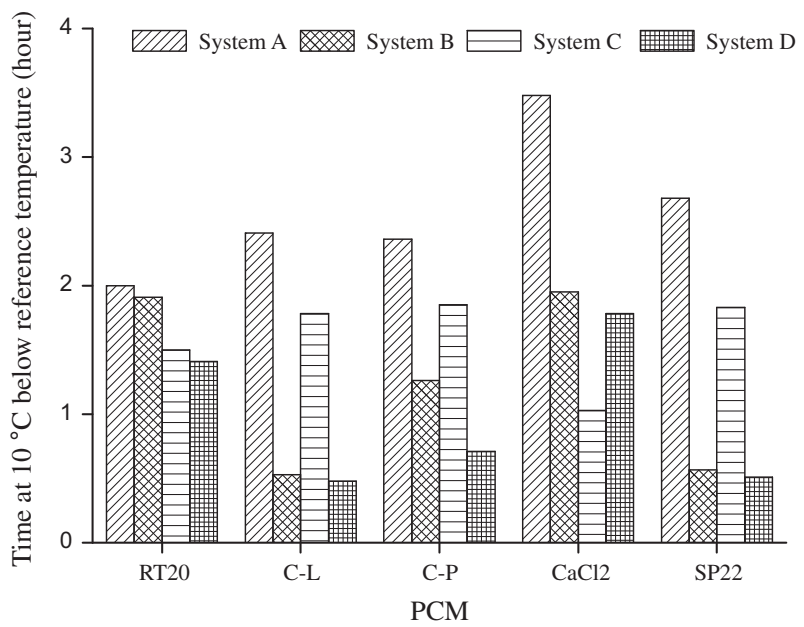

Fig. 8. Duration for which PCM maintained PV front surface temperature $10^{\circ} \mathrm{C}$ below the reference temperature in systems $\mathrm{A}, \mathrm{B}, \mathrm{C}$ and $\mathrm{D}$ at insolation of $750 \mathrm{~W} / \mathrm{m}^{2}$ and ambient temperature of $20 \pm 1^{\circ} \mathrm{C}$. 


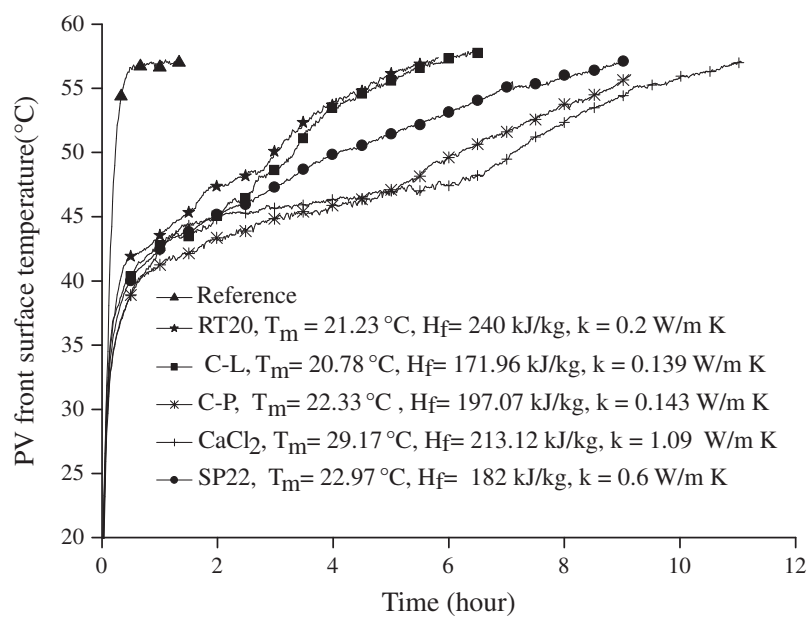

Fig. 9. Temperature evolution on PV front surface in system $\mathrm{A}$ at an insolation of $1000 \mathrm{~W} / \mathrm{m}^{2}$ and ambient temperature of $20 \pm 1{ }^{\circ} \mathrm{C}$.

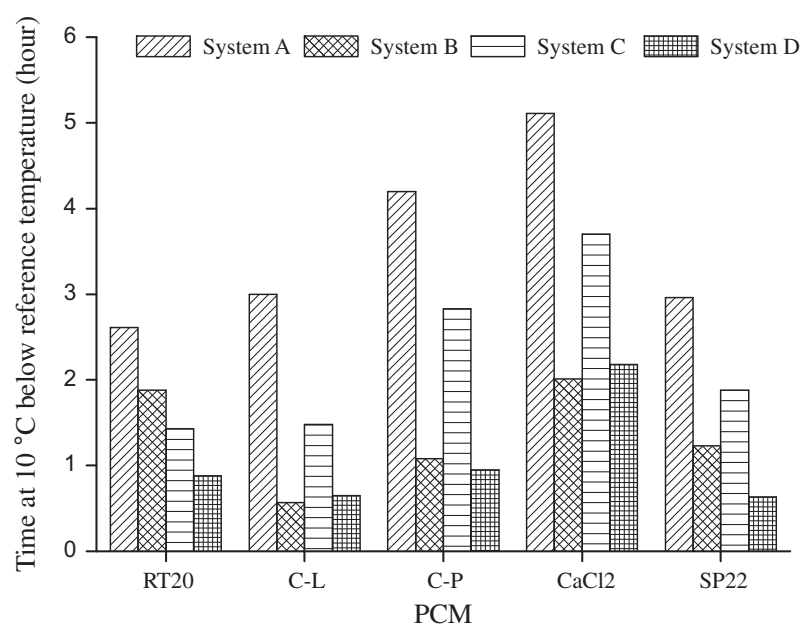

Fig. 10. Duration for which PCM maintained PV front surface temperature $10^{\circ} \mathrm{C}$ below the reference temperature in systems $\mathrm{A}, \mathrm{B}, \mathrm{C}$ and $\mathrm{D}$ at an insolation of $1000 \mathrm{~W} / \mathrm{m}^{2}$ and ambient temperature of $20 \pm 1{ }^{\circ} \mathrm{C}$.

ulation and shorter duration of temperature deviation than in container $\mathrm{A}$.
The duration for which each PCM maintained PV front surface temperature $10{ }^{\circ} \mathrm{C}$ below reference temperature are illustrated in Fig. 10. Comparing containers A, B, C and D, container $\mathrm{A}$ achieved the longest duration of the temperature reduction for all PCMs. Comparing different PCMs, $\mathrm{CaCl}_{2}$ achieved the longest duration of the temperature reduction $(5 \mathrm{~h})$ followed by $\mathrm{C}-\mathrm{P}(4.2 \mathrm{~h}), \mathrm{C}-\mathrm{L}$ and SP22 $(3 \mathrm{~h})$ and RT20 (2.6 h) in system A. It can be concluded that at high insolation, the combination of low thermal conductivity PCM (C-P) with high thermal conductivity system A achieved the largest amount of temperature reduction for shorter duration while the combination of high thermal conductivity PCM $\left(\mathrm{CaCl}_{2}\right)$ with high thermal conductivity system A achieved the longest duration of temperature reduction with smaller amount of temperature reduction.

\subsection{Effect of thermal conductivity of container material of PVIPCM system on PCM performance}

To determine the best container type two PCMs with different thermal conductivities, $\mathrm{C}-\mathrm{P}$ and $\mathrm{CaCl}_{2}$ were characterized in same size systems, $\mathrm{A}$ and $\mathrm{B}$ with different thermal conductivities at $1000 \mathrm{~W} / \mathrm{m}^{2}$ insolation and $20 \pm 1{ }^{\circ} \mathrm{C}$ ambient temperature. Temperatures at $\mathrm{PV}$ front surface using $\mathrm{C}-\mathrm{P}$ and $\mathrm{CaCl}_{2}$ in system $\mathrm{A}$ and $\mathrm{B}$ are illustrated in Fig. 11a and $\mathrm{b}$ respectively. System A maintained lower temperatures at the PV front surface than system $\mathrm{B}$ for both $\mathrm{C}-\mathrm{P}$ and $\mathrm{CaCl}_{2}$ however with $\mathrm{C}-\mathrm{P}$ the temperature difference in $\mathrm{A}$ and $\mathrm{B}$ was higher $\left(\sim 5^{\circ} \mathrm{C}\right)$ than with $\mathrm{CaCl}_{2}$ $\left(\sim{ }^{\circ} \mathrm{C}\right)$.

To compare $\mathrm{C}-\mathrm{P}$ and $\mathrm{CaCl}_{2}$ in same system $\mathrm{A}$, temperatures at $\mathrm{PV}$ front surface are presented in Fig. 11c at $1000 \mathrm{~W} / \mathrm{m}^{2}$ insolation and $20 \pm 1{ }^{\circ} \mathrm{C}$ ambient temperature. C-P maintained lower PV temperature than $\mathrm{CaCl}_{2}$ for initial $\sim 5 \mathrm{~h}$ in low $\mathrm{PV}$ temperature range while $\mathrm{CaCl}_{2}$ maintained lower temperature than $\mathrm{C}-\mathrm{P}$ for rest of the duration of experiment at high PV temperature range. It can be concluded that the lower thermal conductivity PCM (C-P) with lower melting point performs better at lower PV operating temperature while higher conductivity
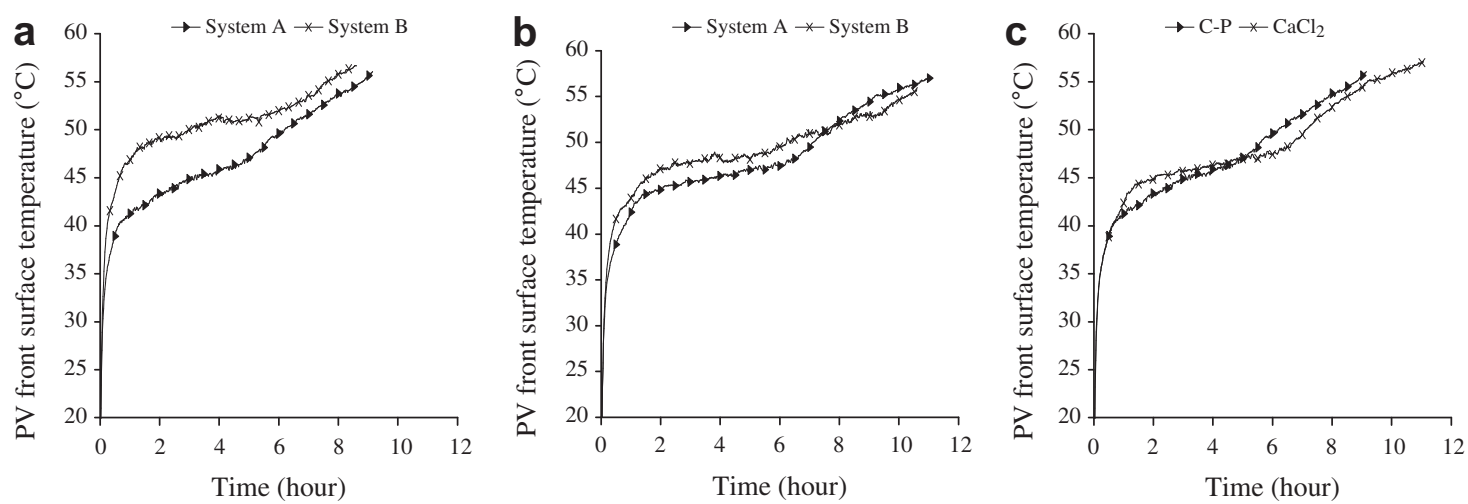

Fig. 11. Temperature at $\mathrm{PV}$ front surface using (a) $\mathrm{C}-\mathrm{P}$ in system $\mathrm{A}$ and $\mathrm{B}$ (b) $\mathrm{CaCl}_{2}$ in system $\mathrm{A}$ and $\mathrm{B}$ (c) $\mathrm{CP}$ and $\mathrm{CaCl}_{2}$ in system $\mathrm{A}$ at an insolation of $1000 \mathrm{~W} / \mathrm{m}^{2}$ and ambient temperature of $20 \pm 1^{\circ} \mathrm{C}$. 
PCM $\left(\mathrm{CaCl}_{2}\right)$ with higher melting point performs better at higher PV operating temperature.

\subsection{Determination of $\Gamma$ for different PCMs}

As described in Eq. (3) $\Gamma$ is a function of (i) deviation of PV temperature with PCM ( $\left.T_{\mathrm{PVPCM}}\right)$ from the reference temperature $\left(T_{\mathrm{PV}}\right)$ and (ii) the duration of the temperature deviation. Appendix $\mathrm{C}$ shows that initially there was no deviation of $T_{\mathrm{PVPCM}}$ from $T_{\mathrm{PV}}$, however, as the PCM commenced melting, this deviation increased and reached its maximum $\left(14-18^{\circ} \mathrm{C}\right.$ in $\left.50 \mathrm{~min}\right)$ where it stabilized for up to $30 \mathrm{~min}$. After the PCM in direct contact with the PV back surface had completed melting and started sensible heating (with a rise in temperature), the adjacent PCM layer still continued to melt and absorb latent heat at constant temperature. This combination of latent and sensible heating of PCM raised the PCM temperature resulting in a decrease in the temperature difference from the reference $\left(10-14{ }^{\circ} \mathrm{C}\right.$ in $\left.100 \mathrm{~min}\right)$. As the melt fraction of PCM continued to increase, the temperature difference continued to decrease. After the PCM had all melted the temperature of PCM and PV front surface started increasing with a larger gradient, so there was the decrease in temperature deviation until $T_{\mathrm{PVPCM}}$ equalled $T_{\mathrm{PV}}$ and the deviation became zero in $\sim 11 \mathrm{~h}$.

$\mathrm{CaCl}_{2}$ and $\mathrm{C}-\mathrm{L}$ achieved the largest temperature deviation of $\sim 18{ }^{\circ} \mathrm{C}$ followed by SP22 and C-P $\left(\sim 16.5^{\circ} \mathrm{C}\right)$, and RT20 $\left(\sim 14{ }^{\circ} \mathrm{C}\right)$. PCM $\mathrm{CaCl}_{2}$ maintained the temperature deviation for the longest duration $(\sim 11 \mathrm{~h})$ followed by $\mathrm{C}-\mathrm{L} \quad(\sim 9.5 \mathrm{~h}), \quad \mathrm{SP} 22 \quad(\sim 9 \mathrm{~h}) \quad \mathrm{C}-\mathrm{L} \quad(\sim 6 \mathrm{~h})$ and RT20 $(\sim 4.5 \mathrm{~h})$. A similar trend was observed with PCM in systems B, C and D. To quantify $\Gamma$ for all PCMs in each system, integrals of the temperature deviation at 500 $\mathrm{W} / \mathrm{m}^{2}, \quad 750 \mathrm{~W} / \mathrm{m}^{2}$ and $-1000 \mathrm{~W} / \mathrm{m}^{2}$ insolation and $20 \pm 1{ }^{\circ} \mathrm{C}$ ambient temperature were plotted illustrated in Appendices D, E and $\mathrm{F}$ respectively.

Appendix D illustrates that at $500 \mathrm{~W} / \mathrm{m}^{2}$, system A achieved the maximum $\Gamma$ value of all PCMs followed by system C, B and D while C and B achieved similar $\Gamma$ values. Since high thermal conductivity system $C$ required 3 / 5 PCM mass compared to low thermal conductivity system $B$, it suggests that $2 / 5$ mass of PCM can be saved by choosing high thermal conductivity system at low insolation. Comparing PCMs, $\mathrm{CaCl}_{2}$ achieved the highest $\Gamma$ followed by $\mathrm{C}-\mathrm{P}, \mathrm{SP} 22, \mathrm{C}-\mathrm{L}$ and $\mathrm{RT} 20$ respectively.

Appendix E illustrates that system A achieved the highest $\Gamma$ at $750 \mathrm{~W} / \mathrm{m}^{2}$ followed by B, C and D. Although all PCMs showed a maximum $\Gamma$ for container A, they differed in containers $\mathrm{B}$ and $\mathrm{C}$. $\mathrm{C}-\mathrm{P}$ and $\mathrm{C}-\mathrm{L}$ gave a marginally higher $\Gamma$ in container $\mathrm{C}$ than $\mathrm{B}$ while $\mathrm{CaCl}_{2}, \mathrm{SP} 22$ and RT 20 gave higher $\Gamma$ in container B than C. Since container $\mathrm{C}$ has higher thermal conductivity than container $\mathrm{B}$, it suggests that it is more appropriate for use with low thermal conductivity PCMs (i.e., C-P and C-L which perform bet- ter in $\mathrm{C}$ than $\mathrm{B}$ ) than for higher thermal conductivity PCMs (i.e., $\mathrm{CaCl}_{2}$, SP22 and RT20 which performed better in $\mathrm{B}$ than $\mathrm{C}$ ). Comparing PCMs, $\mathrm{CaCl}_{2}$ achieved the highest $\Gamma$ followed by $\mathrm{C}-\mathrm{P}, \mathrm{C}-\mathrm{L}, \mathrm{SP} 22$ and RT20.

Appendix $\mathrm{F}$ illustrates that system A achieved the highest $\Gamma$ followed by, B, C and D respectively at $1000 \mathrm{~W} / \mathrm{m}^{2}$. All PCMs showed higher $\Gamma$ in container B than in container $\mathrm{C}$. This was opposite to what was observed at $-500 \mathrm{~W} / \mathrm{m}^{2}$ where all PCMs achieved higher $\Gamma$ in container $\mathrm{C}$ than in container $\mathrm{B}$. It can be concluded that although the increased PV/PCM thermal conductivity yielded higher $\Gamma$ for all PCMs at high insolation (as container A with higher thermal conductivity achieved the highest $\Gamma$ ), however the improvement at $1000 \mathrm{~W} / \mathrm{m}^{2}$ was less than that observed at $500 \mathrm{~W} / \mathrm{m}^{2}$.

\section{Conclusion}

Five PCMs evaluated at three insolations showed that thermal regulation performance of a PCM depends on the thermal mass of PCM and thermal conductivity of both PCM and the over all PV/PCM systems. Comparing PCMs, the salt hydrate $\mathrm{CaCl}_{2}$ achieved highest temperature reduction at most of the insolations. Comparing PV/PCM systems, system A yielded highest temperature reduction and $\Gamma$ with all PCMs. Thermal conductivity of the PCM container had stronger impact on performance of low thermal conductivity eutectics of fatty acids, $\mathrm{C}-\mathrm{L}$ and $\mathrm{C}-\mathrm{P}$. Comparing PCMs the best results were obtained with $\mathrm{C}-$ $\mathrm{P}$ and $\mathrm{CaCl}_{2}$ that maintained a maximum of $18^{\circ} \mathrm{C}$ temperature reduction at $\mathrm{PV}$ front surface for $30 \mathrm{~min}$, while $\mathrm{CaCl}_{2}$ maintained a $10{ }^{\circ} \mathrm{C}$ temperature reduction for the longest duration of $5 \mathrm{~h}$ at $-1000 \mathrm{~W} / \mathrm{m}^{2}$ insolation in system A. Although the results achieved are encouraging however further temperature reduction is necessary to make the PCM financially viable. In a recent unpublished work by authors, increased temperature reduction for longer time durations have been achieved using thermally conductive metallic fins. The proposed PVPCM systems have been reported financially viable with $\mathrm{C}-\mathrm{P}$ and $\mathrm{CaCl}_{2} \cdot 6 \mathrm{H}_{2} \mathrm{O}$ in hot climates at ambient temperature around $34^{\circ} \mathrm{C}$ and solar radiation intensity of $1000 \mathrm{~W} / \mathrm{m}^{2}$.

\section{Acknowledgements}

This work has been supported by the Higher Education Authority through Strand 1 and Strand 3 funding, Science Foundation Ireland through their Research Frontiers Program and the Research Support Unit at Dublin Institute of Technology. The Focas Institute is funded by the Irish Higher Education Authority with assistance from the European Regional Development Fund. Thanks also to Cecil Potterman and Peter O' Farrell for their help in fabrication. 


\section{Appendix A}

Temperature evolutions in reference $\mathrm{PV}$ and $\mathrm{PV}$ with PCM.

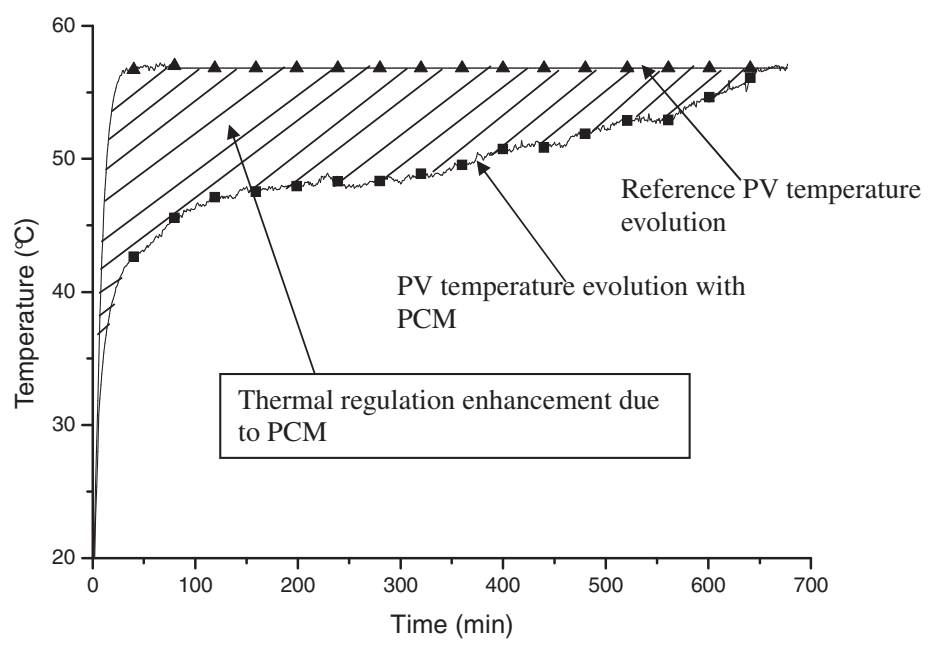

\section{Appendix B}

Temperature deviation curve divided into $n$ discrete measurements to obtain thermal regulation enhancement, $\Gamma$ for a PCM.

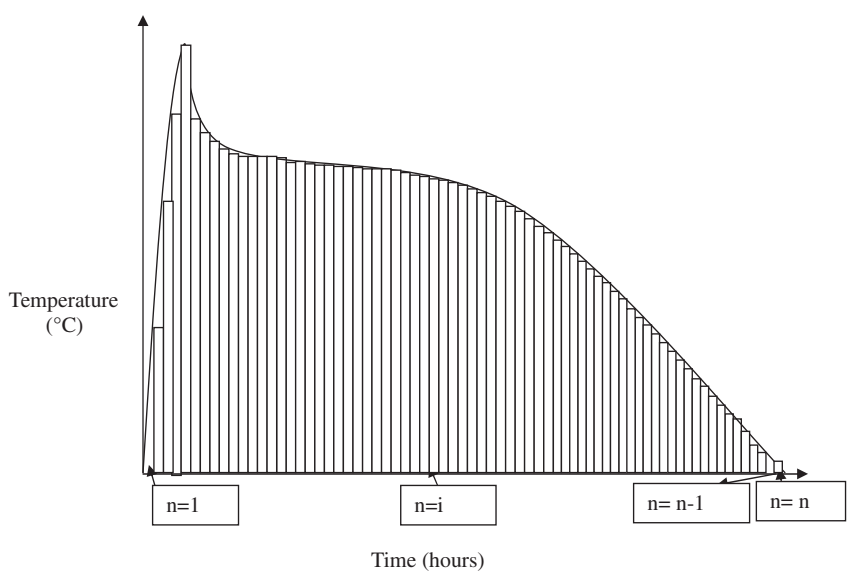

\section{Appendix C}

Temperature difference from reference for RT20, C-L, $\mathrm{C}-\mathrm{P}, \mathrm{CaCl}_{2}$ and $\mathrm{SP} 22$ at an insolation of $1000 \mathrm{~W} / \mathrm{m}^{2}$ and ambient temperature of $20 \pm 1{ }^{\circ} \mathrm{C}$ for system A.

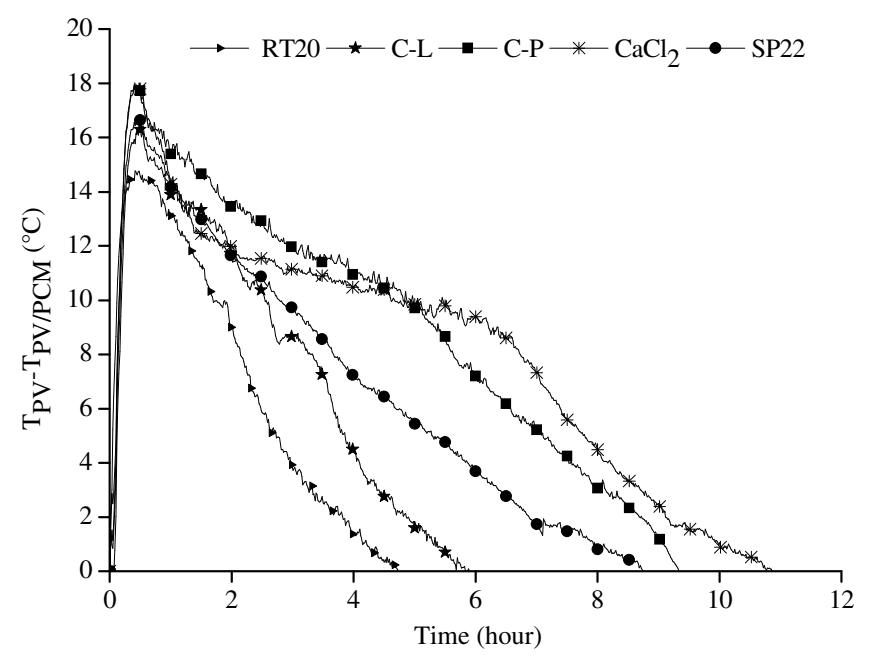

Appendix D. Thermal regulation potential for all PCM at $500 \mathrm{~W} / \mathrm{m}^{2}$ and ambient temperature of $20 \pm 1^{\circ} \mathrm{C}$ in systems A, B, C and D.

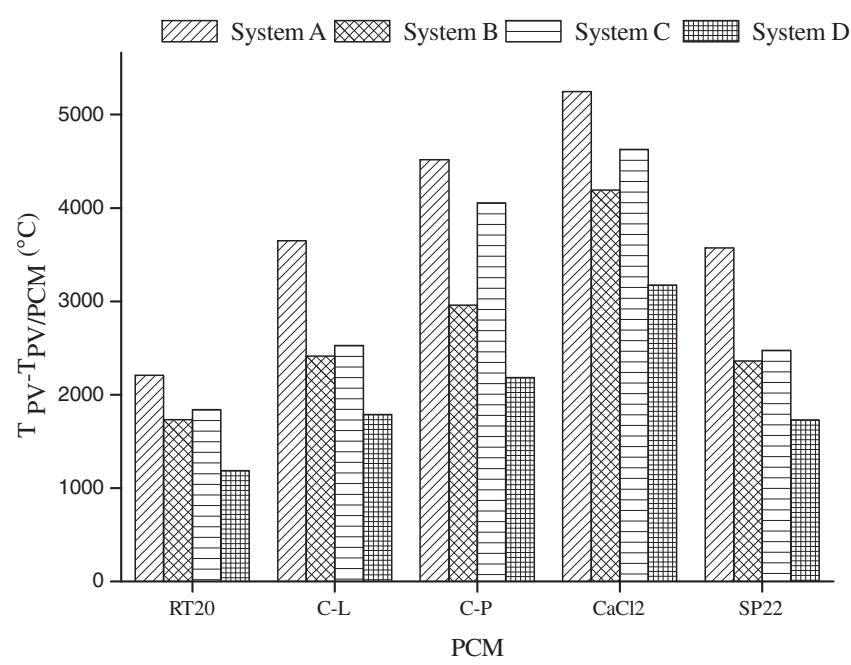


Appendix E. Thermal regulation potential for all PCM at $750 \mathrm{~W} / \mathrm{m}^{2}$ in systems $\mathrm{A}, \mathrm{B}, \mathrm{C}$ and $\mathrm{D}$.

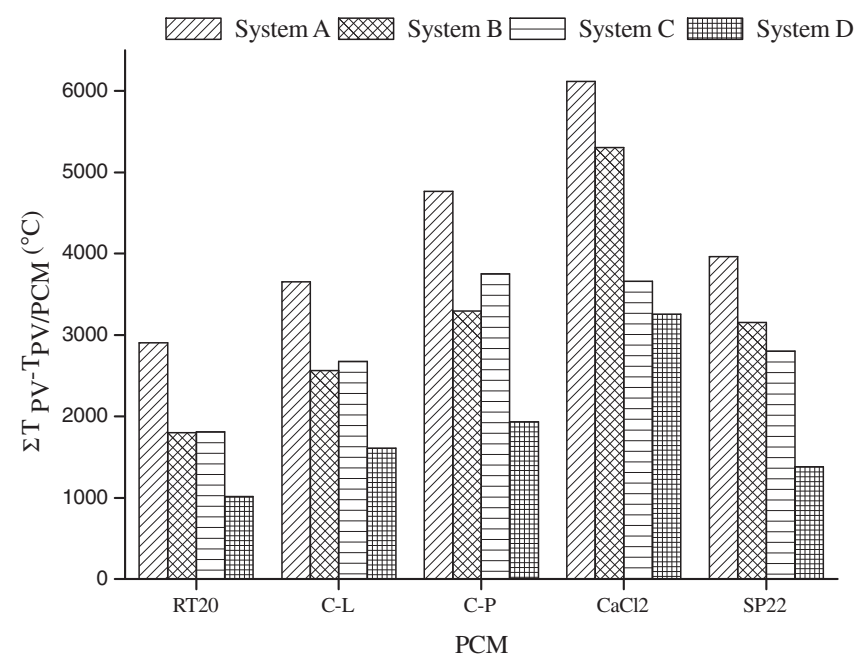

Appendix F. Thermal regulation potential for all PCM at $1000 \mathrm{~W} / \mathrm{m}^{2}$ in systems $\mathrm{A}, \mathrm{B}, \mathrm{C}$ and $\mathrm{D}$.

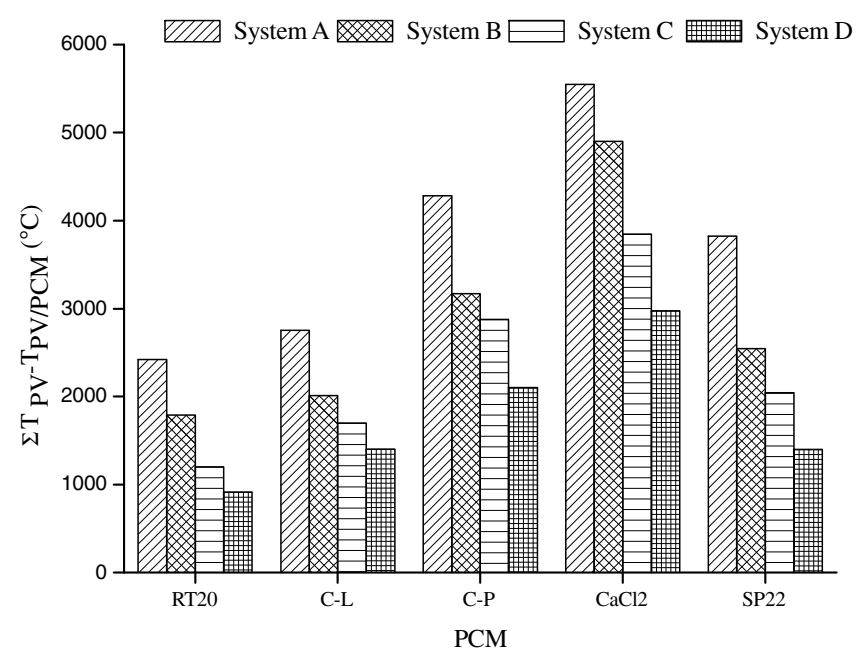

\section{References}

Brinkworth, B.J., 2000a. A procedure for the routine calculation of laminar free and mixed convection in inclined ducts. International Journal of Heat and Fluid Flow 21, 456-462.

Brinkworth, B.J., 2000b. Estimation of flow and heat transfer for the design of PV cooling ducts. Solar Energy 69, 413-420.

Brinkworth, B.J., 2006. Optimum depth for PV cooling ducts. Solar Energy 80, 1131-1134.
Brinkworth, B.J., Sandberg, M., 2006. Design procedure for cooling ducts to minimise efficiency loss due to temperature rise in PV arrays. Solar Energy 80, 89-103.

Fleischer, A.S., Chintakrinda, K., Weinstein, R.D., Bessel, C.A., 2008. Transient thermal management using phase change materials with embeded graphite nanofibers for systems with high power. IEEE 561, 566.

Fossa, M., Ménézo, C., Leonardi, E., 2008. Experimental natural convection on vertical surfaces for building integrated photovoltaic (BIPV) applications. Experimental Thermal and Fluid Science 32, 980-990.

Gan, G., Riffat, S.B., 2004. CFD modelling of air flow and thermal performance of an atrium integrated with photovoltaics. Building and Environment 39, 735-748.

Hasan, A., Schnitzler, E., McCormack, S.J., Huang, M.J., Norton, B. 2007. Phase change materials for thermal control of building integrated photovoltaics: experimental design and findings. In: Proceedings of the 22nd European Photovoltaic Solar Energy Conference and Exhibition, Milan, Italy, pp. 3323-3329.

Hasan, A., McCormack, S.J., Huang, M.J., Norton, B., 2008. Phase change materials for thermal control of building integrated photovoltaics: characterization and experimental evaluation. In: Proceedings of the 4th Photovoltaic Science, Applications and Technology Conference (PVSAT-4), April 2008, Bath, UK, pp. 105-108.

Huang, M.J., Eames, P.C., Norton, B., 2004. Thermal regulation of building-integrated photovoltaics using phase change materials. International Journal of Heat and Mass Transfer 47, 2715-2733.

Huang, M.J., Eames, P.C., Norton, B., 2006a. Phase change materials for limiting temperature rise in building integrated photovoltaics. Solar Energy 80, 1121.

Huang, M.J., Eames, P.C., Norton, B., 2006b. Comparison of a smallscale 3D PCM thermal control model with a validated 2D PCM thermal control model. Solar Energy Materials and Solar Cells 90, 1961-1972.

Ji, J., Han, J., Chow, T.T., Yi, H., Lu, J., Lu, W., Sun, Wei., 2006. Effect of fluid flow and packing factor on energy performance of a wallmounted hybrid photovoltaic/water-heating collector system. Energy and Buildings 38, 1380-1387.

Kandasamy, R., Wang, X.Q., Mujumdar, A.S., 2006. Application of phase change materials in thermal management of electronics. Applied Thermal Engineering 27, 2822-2832.

Khateeb, S.A., Amiruddin, S., Farid, M., Selman, J.R., Hallaj, S.A., 2004a. Thermal management of Li-ion battery with phase change material for electric scooters: experimental validation. Journal of Power Sources 142, 345-353.

Khateeb, S.A., Farid, M.M., Selman, J.R., Hallaj, S.A., 2004b. Design and simulation of a lithium-ion battery with a phase change material thermal management system for an electric scooter. Journal of Power Sources 128, 292-307.

Krauter, S., 1994. Actual optical and thermal performance of PVmodules. In: Proceedings of the 1st World Conference on Photovoltaic Energy Conversion (Joint Congress of IEEE/PVSEC/EUPVC). Waikoloa, Hawaii (USA), December, vol. 1, 734-737.

Krauter, S., 2004. Increased electrical yield via water flow over the front of photovoltaic panels. Solar Energy Materials and Solar Cells 82, 131137.

Krauter, S., Araujo, R.G., Schroer, S., Hanitsch, R., Salih, M.J., Triebel, C., Lemoine, R., 1999. Combined photovoltaic and solar thermal systems for facade integration and building insulation. Solar Energy 67, 239-248.

Lu, T.J., 2000. Thermal management of high power electronics with phase change cooling. International Journal of Heat and Mass Transfer 43, 2245-2256.

Mazer, J.A., 1997. In: Solar Cells: an Introduction To Crystalline Photovoltaic Technology, vol. 108. Kluwer Academic Publications.

Pasupathy, A., Velraj, R., 2008. Effect of double layer phase change material in building roof for year round thermal management. Energy and Buildings 40, 193-203. 
Pasupathy, A., Velraj, R., Seeniraj, R.V., 2006. Phase change materialbased building architecture for thermal management in residential and commercial establishments. Renewable and Sustainable Energy Reviews 12, 30-64.

Pasupathy, A., Athanasius, L., Velraj, R., Seeniraj, R.V., 2008. Experimental investigation and numerical simulation analysis on the thermal performance of a building roof incorporating phase change material (PCM) for thermal management. Applied Thermal Engineering 28, 556-565.

Radziemska, E., Klugman, E., 2002. Thermally affected parameters of the current-voltage characteristics of silicon photocell. Energy Conversion and Management 43, 1889-1900.

Raziemska, E., 2003. The effect of temperature on the power drop in crystalline silicon solar cells. Renewable Energy 28, 1-12.

Sabbah, R., Kizilel, R., Selman, J.R., Hallaj, S.A., 2008. Active (aircooled) vs. passive (phase change material) thermal management of high power lithium-ion packs: limitation of temperature rise and uniformity of temperature distribution. Journal of Power Sources 182, 630-638.

Tan, F.L., Fok, S.C., 2007. Thermal management of mobile phones using phase change materials. In: IEEE 9th Electronics Packaging Technology Conference, pp. 836-842.
Tonui, J.K., Tripanagnostopoulos, Y., 2007. Air cooled PV/T solar collectors with low cost performance improvements. Solar Energy 81, 498-511.

Wang, X.Q., Mujumdar, A.S., Yap, C., 2007. Effect of orientation for phase change material (PCM)-based heat sinks for transient thermal management of electric components. International Communications in Heat and Mass Transfer 34, 801-808.

Weakliem, H.A., Redfield, D., 1979. Temperature dependence of the optical properties of silicon. Journal of Applied Physics 50, 14911493.

Weinstein, R.D., Kopec, T.C., Fleischer, A.S., Addio, E.D., Bessel, C.A., 2008. The experimental extrapolation of embedding phase change materials with graphite nanofibers for the thermal management of electronics. Journal of Heat Transfer 130, 042405.

Yang, H., Marshal, R.H., Brinkworth, B.J., 1994. An experimental study of the thermal regulation of a PV-clad roof. In: Proceedings of the 12th European PV Solar Energy Conference, Amsterdam, 1115-1118.

Yun, G.Y., McEvoy, M., Steemers, K., 2007. Design and overall energy performance of a ventilated photovoltaic facade. Solar Energy 81, 383394. 